\title{
Mediastinal B-Cell Lymphoma, Unclassifiable, with Features Intermediate between Diffuse Large B-Cell Lymphoma and Classic Hodgkin Lymphoma
}

National Cancer Institute

\section{Source}

National Cancer Institute. Mediastinal B-Cell Lymphoma, Unclassifiable, with Features

Intermediate between Diffuse Large B-Cell Lymphoma and Classic Hodgkin Lymphoma.

NCI Thesaurus. Code C37870.

A mediastinal lymphoma with molecular, morphologic, immunophenotypic, and clinical features of both mediastinal (thymic) large B-cell lymphoma and classic Hodgkin lymphoma. The identification of this group of lymphomas, along with recent gene expression profiling results (PDL2 gene expression in both mediastinal (thymic) large Bcell lymphoma tissues and Hodgkin lymphoma cell lines), further supports the hypothesis that mediastinal (thymic) large B-cell lymphomas and classic Hodg kin lymphomas are related entities. 